\title{
Appraising English Language Teachers' Self-Reports of Readiness to Manage Large Reading Comprehension Classes in Selected Secondary Schools in Ibadan, Nigeria
}

\author{
Samson Olusola Olatunji \\ University of Ilorin, Kwara State, Nigeria \\ samsholat@gmail.com
}

\begin{abstract}
This paper is based on a survey that was carried out to find a statistically valid picture of English Language teachers' attitudes to the teaching of reading comprehension to large ESL classes in the Ibadan metropolis of southwestern Nigeria. The pedagogic practices of the teachers in such a challenging but potentially rewarding situation were also investigated. The far-reaching importance of reading comprehension to the overall success of students in light of frequent failure in major examinations justify the study. The study sample was obtained through a multistage procedure. A total of ninety-eight teachers responded to a fourteen-item selfconstructed questionnaire that had yielded 91.2 reliability coefficient. The findings of the data analysis reveal that most of the teachers consider any class of thirty-one students and above as large, the teachers are ill-disposed to large classes, and they neglect to employ any unusual strategies to make teaching reading comprehension both interesting and highly rewarding to either teacher or students.
\end{abstract}

\section{Background to the Study}

The task of language teaching is extremely intimidating when the class is excessively large. If it is a reading comprehension class of learners with varying degrees of reading readiness in need of special attention, a teacher may be overwhelmed by a sense of helplessness and hopelessness. But the development of the skills for reading comprehension in learners is sine qua non for successful guided learning and independent study.

Large classes are a common feature of public schools in Nigeria (Maingi, Mulwa, Maithya, \& Migosi, 2017). To worsen the matter, most children enrolled in public schools are from poor families that find reading texts unaffordable while children from elitist families as well as many from struggling parents are enrolled in fee-collecting private schools where every student has all recommended textbooks paid for as part of the school fees (Aladejana, 2007; Adebayo, 2009). In order to attract and sustain considerable patronage, proprietors of private secondary schools in Nigeria employ only teachers that demonstrate deep content knowledge and excellent pedagogic skills during rigorous selection exercises (Adebayo, 2009). But since the people saddled with the responsibility of teacher selection for public schools send their own children to private secondary schools as a matter of norm, they often disregard merit and elevate less salient factors bordering on tribalism and nepotism (Maduewesi \& Ihebereme, 2010; Nwokeoma, 2010). This, however, does not automatically mean some of the most competent teachers do not get employed to teach in public schools. Similarly, some less competent teachers do find their way into private secondary schools. But there is normally a generally greater degree of commitment to internal quality control measures to ensure private secondary school teachers are kept working hard than is obtainable in most public secondary schools. 
Because over $70 \%$ of Nigerians live below what the United Nations described as the poverty line of $\$ 1$ per day (Okediran \& Olatunji, 2010), most Nigerians cannot afford to send their children to the private secondary schools that maintain modest class sizes of a maximum of thirty students. Most children are thus enrolled in public secondary schools that keep large classes overcrowded with students ranging from sixty-five to over one hundred students in which those with required textbooks may not be more than ten (Amanchukwu \& Ololube, 2015; Oleforo \& Maxwell, 2015; Maingi, Mulwa, Maithya \& Migosi, 2017). These constitute double sources of troubles to the teachers in the public secondary schools who, to compound their challenges, are grossly inadequately motivated with little and irregular or grossly delayed salaries (Akanbi, 2014).

The language situation in Nigeria, of which Ibadan is a major city, is not very favourable to the teaching and learning of English comprehension skills. The indigenous languages in Nigeria are reported to be about 450 (Okebukola, Owolabi \& Okebukola, 2013). Nigeria is reportedly one of the most linguistically heterogeneous countries of the world (Danladi, 2013; Emeka-Nwobia, 2015).

It is noteworthy that Ibadan, the geographical scope of the current study, is a city in the Yoruba-speaking southwestern part of Nigeria. The southwestern Nigeria is monolithic. Yoruba is the only indigenous language, but with various dialects. The place is thus also named Yoruba land. So, generally, Yoruba is the mother tongue of children in that region of Nigeria while English, the only functional official language, is second. But there is a trend in which elitist families and those of middle class civil servants either exclusively speak English to their children or adopt both English and Yoruba as home languages, with special preference for the former which they perceive as a ticket to global relevance and prominence (Osoba \& Alebiosu, 2016).

Formerly, the National Policy on Education (NERDC, 1998, revised 2004) stipulated that the mother tongue of a child or the indigenous language of the immediate environment of the school should be language of instruction from the pre-primary to the end of the third year of primary school when English should take over progressively as language of instruction. Up till this point, the English language was to be taught as a school subject to prepare a smooth transition. As from the beginning of the fourth year, the indigenous languages were to be taught as school subjects. An amendment introduced in the 2013 edition of the National Policy on Education is that the period of the use of indigenous languages as media of school instruction has been extended to the end of the fourth year and the progressive switch-over to the English language postponed to the same time (NERDC, 2013).

Studies carried out in Ibadan and other southwestern Nigerian cities have, however, shown widespread disregard for the policy stipulation. Most private nursery and primary schools follow their self-formulated straight-for-English policy. English is the medium of instruction right from the child's first day of preprimary education. English is the home language of many elitist children that attend such private schools, too. In fact, many people from such elitist homes would withdraw their children from any school that fails to teach through the medium of the English language. In private secondary schools, therefore, the policy stipulating English as medium of instruction for all school subjects (except in the teaching of Nigerian indigenous languages as school subjects) is generally largely adhered to.

In the public primary schools, however, the switch-over to English as medium of instruction is scarcely implemented as most teachers are often constrained by pupils' limited English proficiency. It is common to hear teachers employing Yoruba language to teach even Journal of Contemporary Issues in Education, 2017, 12(2), pp. 2-17. ISSN 1718-4770 @ 2017 University of Alberta/Centre for Global Citizenship Education and Research http://ejournals.library.ualberta.ca/index.php/JCIE 
English Language in public secondary schools in the southwestern parts of Nigeria and the indigenous languages in the other parts as applicable. Most students in Nigerian public secondary schools are from homes where English is either clearly a second language or it is not spoken at all because the parents are not English-literate.

The English as a Second Language (ESL) teacher in a Nigerian public secondary school thus needs to learn necessary strategies to help the students, despite the limitations described above and their well reported poor reading culture (Olaotan \& Ogunleye, 2013), to develop interest in reading comprehension exercises. Helping the students to overcome their deficiencies is further compounded by the overcrowded nature of most of the public secondary classrooms. Therefore, the current study examined the concerned teachers' preparedness to take on the daunting task of teaching reading comprehension in a large class.

\section{Challenges of Teaching Reading Comprehension in a Large ESL Class and Practices in Contexts}

Most language teaching and learning programmes are aimed at developing in learners one or any combination of four basic skills, namely listening, reading, speaking and writing in the target language. The teaching of English language is not in any way an exception. Each of the language skills has its own unique importance and advantages. The major concern of this study is reading, of which reading comprehension is a sub-set.

Reading has been variously described by many authors because, according to Onukaogu (2003), it is too deep and broad for mere definition. But reading can be explained as the art and science as well as the process and product of extracting meaning from a written or printed text. "Comprehension" is a synonym of "understanding". Reading comprehension can, therefore, be conceived as the process and product of reading a text meaningfully and getting enough understanding from it in order to answer questions of varying degrees of difficulty and reproducing the text in one's own words (Onukaogu, 2003).

Reading comprehension is accorded great significance in language learning and testing. In English Language Paper I of the West African Examination Council's senior secondary school certificate examination as well as that of the National Examination Council, every candidate is required to attempt two comprehension exercises. This can be justified with the general observation that reading is fundamental to success in any academic endeavour since it is a means of independent knowledge acquisition and revision (Willis \& Willis, 2007; Arikan, 2008) as well as a means of receiving instructions during examinations. Indeed, reading comprehension skill is an invaluable instrument for overcoming learning challenges (Ozkan \& Tongur, 2014).

Reading comprehension is one of the components of the lessons in general English Language classes in Nigeria. Reading comprehension is thus taught and tested and the performance in it is taken along with performance in other aspects such as test of orals, essay writing, summary writing, and lexis and structures to determine the overall achievement score in English Language. Since a credit pass in English is mandatory for candidates' admission to any course of study in a Nigerian tertiary institution (Iroegbu, 1997; Olatunji, 2000; Osisanwo, 2005) and ability to comprehend what is read in preparation for an examination as well as the actual examination questions is essential, the reading comprehension skills of students would significantly determine the students' scores in English Language and other school subjects. 
Each English Language textbook normally recommended for use in the Nigerian schools contains all the afore-listed aspects of English Language studies (reading comprehension, test of orals, essay writing, summary writing, lexis and structures or grammar). Reading comprehension is thus expected to be taught once in a week during an English Language lesson period. A particular comprehension passage in the recommended English Language textbook is chosen for the exercise. One of the inevitable deficiencies of such books is that they cannot take care of every student's reading interest because every class comprises students with diverse areas of interest (Worthy, Moorman \& Turner, 1999). The larger the class, the more compounded the challenge.

The fact that most Nigerian students have been observed to be non-readers and poor performers in reading comprehension exercises (Kolawole, 2005; Christopher, 2006; Olaotan \& Ogunleye, 2013) shows that the teaching of reading comprehension skill, which is described as the most important academic language skill (Gilakjan \& Ahmadi, 2011), has not been as effective as required. Students in southwestern Nigeria (where Ibadan is located), according to Kolawole (2005, p. 101) "find it difficult to read for the gist". In the words of Emenanjo (2014, p. 7), "Nigerians are neither great lovers, great buyers, avid readers nor fanatical users of books". The factors militating against proper teaching of reading comprehension skill range from paucity of appropriate texts, poverty that prevents many parents from equipping their children with adequate learning materials (Kainuwa \& Yusuf, 2013), general lackadaisical attitude to learning, overcrowded classrooms, time-tabling challenges (Roessingh \& Field, 2000), teachers' inadequate pedagogic skills to teachers' attitudes to large classes.

Of importance to this study, however, is the problem of overly large classes with its attendant challenges. Sharndama (2013) observes that "there is no universally accepted number of students that constitute a large class; some institutions use the term "large" to refer to classes of more than fifty students, while others regard a large class as one with more than one hundred students" (p. 35). Treko (2013) interrogates the concept of a large class by reviewing submissions from different authors and observes that a class of 30 and above is considered large by Hess (2001) while Ur (1996) puts it at 40 to 50 students (Treko, 2013, p. 243). There is a consensus among scholars that the concept of large classes is so multi-faceted and multidimensional that the explanations given vary from nation to nation, teacher to teacher, school to school, discipline to discipline, dispensation to dispensation, and so on (Imitaz, 2014). What is considered a large class in a private school, for example, is a normal class in a public school (Thaher, 2005; Bradley \& Green, 2011). Among the characteristic features of a large class is that the class' numerical strength is too overwhelming for the teacher's coping ability, effectiveness and efficiency (Pedder, 2006), thus resulting in a negative attitude to work in both teacher and students (Abioye, 2010). It is almost practically impossible to know every student by name and give each personal attention (Thaher, 2005), students are significantly multi-level as regards readiness to master learning tasks (Roberts, 2007), grading of assignments is extremely cumbersome to the teacher (Nevara \& Greisamer, 2010), noise may be inevitable (Hayes, 1997) and the teacher may become wearied while unconsciously shouting louder and walking more often than necessitated in moderate classes (Hansen \& Hasan, 2015). Students' chance to effectively participate in language learning tasks is greatly reduced and they are consequently disenfranchised, space for easy movement of teacher and students is likely to have been reduced (Bahanshal, 2013), and physical resources become inadequate (Imitaz, 2014). Consequently, 
traditional methods of teaching cannot produce desired instructional objectives in a large class, more importantly in English as a Second Language (ESL) classes (Mirvan, 2013).

This places a great deal of responsibility on the ESL teacher who must do more than what produces good results for a teacher in an average-size classroom. For instance, Van Lier (2014) observes that strategies that produce great results in large language classes require planning and organisation that may be rigorous initially. It is noteworthy that the non-native status of the students in an ESL/EFL situation compounds the challenges inherent in large classes (Treko, 2013). It is thus not every language teacher that can teach reading comprehension passages to a large class.

Some scholars have asserted that a large class that is taught by an effective and efficient teacher that possesses the necessary skills is advantaged because it affords richer human resources and greater potentials for cooperation, creativity and innovation than smaller classes (Hess, 2001; Wang \& Zhang, 2011). But the proviso for exploiting the advantages of a large class is not ordinary. The teacher must be above average in content knowledge and pedagogic skills (Okebukola, 2012).

It should also be noted that the desire to minimize cost and maximize profit can be an overwhelming temptation to both private school owners and governments to prefer large classes (Todd, 2006). The only difference is that because parents usually pay substantial amounts of money to keep their children/wards in private schools, they can demand modest size classes (Adebayo, 2009). But even private schools are at different levels of sophistication. The very cheap ones are ill equipped and serve the poor people, the ones charging modest fees provide arguably commensurate services to the middle class, and others with international standards in terms of human and material resources serve the super-rich upper class. Each of the categories of students has peculiar instructional needs that must be catered for if the reading comprehension lessons would record success. So, English Language teachers need to get prepared to face the reality instead of wishing endlessly that large classes will someday shrink into small sizes.

A teacher with adequate skills can turn a large ESL class into a place for maximal success. This is corroborated by Treko's (2013) assertion that the teacher's efficiency is one of the reliable yardsticks for judging an ESL class as large or small. In an experiment in which taskbased instruction was used to teach a large English as a Foreign Language class in Taiwan, significant improvement was recorded (Zhang \& Hung, 2013). Efficient teachers employ a student centred and cooperative instructional strategy and communicative approach in their reading classes (Suh, 2009). Critical pedagogy is another instructional strategy employed by Barjesteh, Alipour \& Vaseghi (2013) to achieve significant improvement in students' attitude to reading comprehension as well as performance in a large Iranian ESL classroom.

One of the strategies reported to have helped increase students' interest resulting in better performance in reading comprehension exercises is the use of excerpts from literary texts carefully chosen to conform to students' reading interests (Ozkan \& Tongur, 2014; Yugandhar, 2013; Yadav, 2014). The literary texts are not to be chosen without a prior verification of the students' reading interest (Arikan, 2008). No matter how informative and enlightening a passage and its topic may be, the students will not put in the degree of seriousness required for comprehension if they do not have interest in the topic (Brantmeier, 2006). Reinders and Balcikanli (2011) too agree that textbook passages are usually not fascinating enough to students and therefore do not promote learner autonomy. Unfortunately, it is hard to find reading passages that will be of interest to every student in the course books recommended for use in a particular 
class (Worthy, Moorman \& Turner, 1999). The types of stories that are likely to arrest and retain the reading interest of the present-day class are those involving love, romance, soccer, and gossip texts about popular musical or theatre artists. The experimental group with which literary texts were chosen by students themselves in the study reported by McNabb (2013) demonstrated significantly improved attitude and performance in reading comprehension exercises while the control group that used textbook passages did not. Yadav (2014) also emphasises serious consideration of the cultural backgrounds of learners when selecting a literary text for use in an English language teaching situation.

Yugandhar (2013) recommends the practice of reading together as the best strategy to enhance students' reading skills and empower them in the subject knowledge. The Communicative Language Teaching approach, in which students are encouraged to share one another's thoughts and feelings in a collaborative environment, has also been found helpful in significantly diminishing the negative effects of large English Language classes. Inyang and Onukaogu (2003), too, advocate reading clubs culture as a significant catalyst to an improved attitude to reading. When all members of the reading club have been helped to develop interest and confidence, the relationship between the teacher and the students in the large ESL class transforms from dependence to independence (Chowdhury, 2012). Reaching this stage successfully means the teacher's work burden has become so light that more success can be achieved much more easily in the large ESL class than a less proficient teacher could record in an unarguably small class. Bahanshal (2013) also recognises the immense advantage of the diversion of a lot of classroom responsibilities to students by teachers in a large language class.

The deployment of information and communication technologies (ICTs) can also help the teacher in a large language class to teach comprehension effectively (Sharndama, 2013). A good public address system can compel students to listen to instructions in reading comprehension in a large class. Computer-based tests, too, can engender interest. The use of video-based instruction in an experiment by Xhemaili (2013) in a large ESL class produced significant improvement in students' interest and performance in reading comprehension as well as the other language skills.

Extant literature, some of which has been reviewed so far, shows that a teacher's attitude to a large class is more crucial to the teacher's success in the teaching endeavours than the largeness of the class itself. Nevara and Greisamer (2010) thus assert that the possession of a positive disposition to professional self-development can turn a large class into a wealth of resources for a teacher. Teachers' attitudes determine how they plan their work, what instructional choices they make, how they interpret and implement teaching in terms of choice of activities and other crucial issues (Jimakorn \& Singhasiri, 2006). It will thus be a worthwhile venture investigating the attitude of Nigerian English Language teachers as regards large ESL classes. This is with a view to determining if the teachers need assistance in developing the very important attitudinal skills in managing large classes.

Literature is also replete with instances of theoretical as well as empirical evidence of the efficacy of some pedagogic practices in making teaching language skills in general and reading comprehension in particular to large ESL classes interesting and fruitful to both teachers and students. It will be reasonable to find out if non-engagement in such practices by English Language teachers in Nigerian ESL classes is one of the causes of the unimpressive performance of their students in English Language reading comprehension exercises. If the teachers are found to unsuccessfully employ such strategies that have produced results elsewhere, there will be a clearer direction for further research. This is necessary in view of Shamim's (1993)

Journal of Contemporary Issues in Education, 2017, 12(2), pp. 2-17. 
recommendation of instructional method improvement rather than the reduction of large classes as the most reasonable step towards effective language teaching in large classes.

The attention given to research on the effects and solutions to the problems posed by large classes in developing countries is much less than what obtains in developed nations (Bahanshal, 2013). This is rather paradoxical because the developing countries are the ones most affected by the issue of large classes and inadequate educational resources. Carrying out a study like this in Nigeria that is a developing country is, therefore, a necessity.

Ibadan metropolis has been at the forefront of development in and beyond Oyo State of Nigeria as the place of the first television station in Africa, the first university in Nigeria and the first Nigerian stadium, among other developments. As the most urbanized city in Oyo State, resulting from its privileged status as the capital city of the whole of the old Western Region of Nigeria, most teachers struggle to be posted to schools in Ibadan while only the less fortunate are posted to peri-urban as well as rural areas without adequate modern facilities in the state. The urban and cosmopolitan condition of the city also gives it an edge over other places in the state in terms of availability of instructional materials, mega bookshops and libraries. It is expected that whatever is observed as the practices of English Language teachers, or any other subject for that matter, in Ibadan must be the state-of-the-art in the whole state. Hence, it is logical to expect the best practices of reading comprehension teaching and learning in Ibadan as far as Oyo State is concerned.

It is noteworthy that in Ibadan, as in other parts of Nigeria, overcrowding is a common feature of classrooms in public schools. Akanbi $(2014$, p. 15) shows a photograph of a large public secondary school class in southwestern Nigeria learning under an open heaven with only a big tree covering the students with its leafed branches. The non-uniformity of the students' chairs betrays the fact that each student brings his/her chair from home. Ibadan metropolis is, however, much better off than most other places in the region.

The Nigeria Certificate in Education (NCE) awarded by colleges of education is the least qualification to teach in a secondary school. Preference is given to university degree holders to teach the senior secondary classes. The NCE holders must have been taken through two courses in language pedagogy usually named English Methods or English Teaching Methods I and II in two semesters respectively. The courses are designed to equip pre-service teachers, or even those undergoing in-service teacher education programmes, with the knowledge of the approaches, methods and strategies/techniques employed in teaching the various components of English studies, including reading comprehension. At the university level, two English Language Methods courses are offered as well. The courses, like those at the college of education level, are meant to prepare the beneficiaries with skills for teaching all aspects of English studies. Some institutions (e.g. Lead City University, Ibadan) have even included a separate course named Microteaching solely for practical demonstration of teaching strategies among their teacher education students.

Ogunbiyi (2004) has, however, noted that most Nigerian teachers still lack knowledge of new trends in pedagogy and therefore keep on employing old techniques all the way. Ogunbiyi (2004) further observes that most lecturers, though aware of latest developments and methods in the education industry, are incapacitated by lack of facilities from passing down new trends in pedagogy to their students. Their students do not understand much of what such lecturers have put in publications concerning the new teaching methods. It is the conviction of the author of the current piece that since a good number of the lecturers are aware of new pedagogic innovations, 
lack of facilities can only constrain them from demonstrating such innovations extensively, but they can still teach the new strategies with improvised facilities or, at worst, theoretically. It is thus safe to conclude that the beneficiaries of English language teacher education programmes must have been made aware of new strategies that have produced good results in reading comprehension classes in other countries.

\section{Materials and Method}

The survey was conducted to ascertain the attitudes and current pedagogic practices of English Language teachers in the Ibadan metropolis for the teaching of reading comprehension to students in large secondary school classes. A total of 98 English Language teachers participated through a multistage sampling procedure. The first stage took the form of purposive selection of the five local government areas constituting Ibadan metropolis. This was based on the consideration of the fact that the metropolis is a place where best practices in all spheres of life can be expected in Oyo State. Eight secondary schools were sampled randomly from each of the local government areas, thus making a total of forty secondary schools. Every English Language teacher in each sampled school was automatically included, subject to availability and readiness to participate.

A copy of a self-constructed fourteen-item questionnaire was administered to each respondent. The questionnaire is divided into three sections. Section A contains three items requesting demographic information: age, highest educational qualification and years of teaching experience. Section B comprises seven items that seek information about each respondent's attitude to the teaching of reading comprehension skills to a large ESL class. The four-item forced-Likert-scale Section C requires information about each teacher's experience with large classes in the teaching of reading comprehension passages. The response options for items 5 to 14 were Strongly Agree (SA), Agree (A), Disagree (D) and Strongly Disagree (SD). Each response was scored 1 because the items were used for frequency and percentage statistics alone.

Copies of the questionnaire were trial-tested on 30 teachers that had similar qualifications but were not included in the actual study sample. Their responses were subjected to validation through the Statistical Package for the Social Sciences (SPSS) that yielded 91.2 Cronbach alpha. Copies were then personally administered to the sampled teachers in their respective schools. The collected data were analysed with the statistical tools of frequency counts and percentages.

\section{Findings}

Table 1: Distribution of the Respondents According to Age

\begin{tabular}{|l|c|c|}
\hline Age Brackets & Frequencies & Percentages \\
\hline $20-30 y r s$ & 6 & 6.12 \\
\hline $31-40 y r s$ & 24 & 24.49 \\
\hline $40-50 y r s$ & 54 & 55.10 \\
\hline $50-60 y r s$ & 14 & 14.29 \\
\hline 61 yrs and above & - & - \\
\hline Total & $\mathbf{9 8}$ & $\mathbf{1 0 0}$ \\
\hline
\end{tabular}

Journal of Contemporary Issues in Education, 2017, 12(2), pp. 2-17. 
Table 1 shows that only $6(6.12 \%)$ of the teachers are from 20 to 30 years of age, $24(24.49 \%)$ from 31 to 40 years of age. Those from 41 years and above total $68(69.39 \%)$. The implication of this data is that a great majority of the teachers are old enough to have had much experience of teaching large classes. They are also expected to have developed enough emotional resilience to withstand the challenges of a large class.

Table 2: Distribution of the Respondents According to Years of Teaching Experience

\begin{tabular}{|l|c|c|}
\hline Teaching Experience & Frequencies & Percentages \\
\hline Below 5 yrs & 2 & 2.04 \\
\hline $5-10$ yrs & 22 & 22.45 \\
\hline $11-20$ yrs & 26 & 26.53 \\
\hline $21-30 y r s$ & 48 & 48.98 \\
\hline 31 yrs and above & - & - \\
\hline Total & $\mathbf{9 8}$ & $\mathbf{1 0 0}$ \\
\hline
\end{tabular}

Table 2 indicates that not less than $75.51 \%$ of the respondents can be described as veterans (26.53\% have from 11 to 20 years of experience and $48.98 \%$ have invested from 21 to 30 years in ESL teaching). They can thus be expected to represent the state-of-the-art of English Language teaching in general and reading comprehension teaching in particular. It is also an indication that recent recruitment of new staff into the teaching service by the state has not been as frequent and robust as required.

Table 3: Distribution of the Respondents According to Highest Educational Qualifications

\begin{tabular}{|l|c|c|}
\hline Qualification & Frequencies & Percentages \\
\hline Below 1st Degree & - & - \\
\hline 1st Degree & 68 & 69.39 \\
\hline Postgraduate Diploma in Education & 18 & 18.37 \\
\hline M.Ed. & 12 & 12.24 \\
\hline Ph.D. & - & - \\
\hline Total & $\mathbf{9 8}$ & $\mathbf{1 0 0}$ \\
\hline
\end{tabular}

Table 3 further indicates that the sample can be reasonably expected to be representative of the language teaching population that offers the best practices obtainable in terms of training and experience. None of them ranks below the first degree, $69.39 \%$ have the first degree, and $18.37 \%$ possess the Postgraduate Diploma in Education while 12.24\% have bagged the Masters Degree in Education. 
Table 4: Statistical Representation of the Respondents According to Conceptions of Large Class

\begin{tabular}{|l|l|c|}
\hline $\begin{array}{l}\text { What number of students do you } \\
\text { consider the beginning of a large class? }\end{array}$ & Frequencies & Percentages \\
\hline 31 students and above & 56 & 57.15 \\
\hline 40 students and above & 30 & 30.61 \\
\hline 45 students and above & 12 & 12.24 \\
\hline 50 students and above & - & - \\
\hline 55 students and above & - & - \\
\hline 60 students and above & & \\
\hline Total & $\mathbf{9 8}$ & $\mathbf{1 0 0}$ \\
\hline
\end{tabular}

Table 4 shows that the greatest percentage of the teachers (57.15\%) defines a large class as containing 31 students upwards. This opinion reflects the thirty-students-per-class policy of the government in power in Oyo State from 2003 to 2007. But succeeding governments have jettisoned the policy and the case has reverted to the previous overcrowded situation.

Furthermore, $30.61 \%$ believe that a large class begins from forty students per class while $12.24 \%$ considers a large class beginning from 45 students.

\section{Answering the Research Questions}

Research Question 1: What is the teachers' attitude to the teaching of reading comprehension in a large ESL class?

Table 5: Statistical Presentation of the Responses Indicating the Teachers' Attitude to Reading Comprehension Teaching in a Large ESL Class

\begin{tabular}{|l|l|l|l|l|l|l|}
\hline S/N & Item & SA & A & D & SD & Total \\
\hline 5 & $\begin{array}{l}\text { Teaching reading comprehension in a large class } \\
\text { can be real fun. }\end{array}$ & 1 & 3 & 10 & 84 & $\mathbf{9 8}$ \\
\hline 6 & $\begin{array}{l}\text { Teaching reading comprehension in a large class } \\
\text { maximizes the teacher's instructional time. }\end{array}$ & 20 & 6 & 6 & 66 & $\mathbf{9 8}$ \\
\hline 7 & $\begin{array}{l}\text { Teaching reading comprehension in a large class } \\
\text { affords the teacher the benefits of extensive } \\
\text { impact through peer-tutoring and group } \\
\text { assignments. }\end{array}$ & 13 & 21 & 48 & 16 & $\mathbf{9 8}$ \\
\hline 8 & $\begin{array}{l}\text { Assessment of students' assignments in a large } \\
\text { ESL class may not necessarily be more } \\
\text { cumbersome than what obtains in a small class. }\end{array}$ & 2 & 3 & 36 & 57 & $\mathbf{9 8}$ \\
\hline
\end{tabular}

Journal of Contemporary Issues in Education, 2017, 12(2), pp. 2-17. 


\begin{tabular}{|l|l|c|c|c|c|c|}
\hline 9 & $\begin{array}{l}\text { I am not bothered whether the class I am to teach } \\
\text { reading comprehension to is large or small. }\end{array}$ & 4 & 2 & 54 & 38 & $\mathbf{9 8}$ \\
\hline 10 & $\begin{array}{l}\text { Every student in a large class can enjoy adequate } \\
\text { attention and participation in a reading } \\
\text { comprehension exercise. }\end{array}$ & 2 & 4 & 50 & 42 & $\mathbf{9 8}$ \\
\hline \multicolumn{2}{|c|}{ Total } & $\mathbf{4 2}$ & $\mathbf{3 9}$ & $\mathbf{2 0 4}$ & $\mathbf{3 0 3}$ & $\mathbf{5 8 8}$ \\
\hline
\end{tabular}

Key:

$\mathrm{SA}=$ Strongly Agree

$\mathrm{A}=$ Agree

$\mathrm{D}=$ Disagree

$\mathrm{SD}=$ Strongly Disagree

Table 5 shows that a total of the 588 responses were obtained in relation to the teachers' attitudes to the teaching of reading comprehension in a large class. The highest number of responses (303) indicates strong aversion to the teaching of reading comprehension to a large ESL class while the next (204) simply disagree with the idea of teaching reading comprehension to a large class. The responses in agreement with the teaching of reading comprehension in a large ESL class total 81 (Strongly Agree $=42$ and Agree = 39). The implication of this is that most teachers would be demoralized at the sight of a large class and much worse when faced with the challenges of teaching reading comprehension to the large class.

Considering the observation that teachers' attitudes strongly impact their teaching performance, effectiveness and efficiency (Nevara \& Greisamer, 2010), it can be concluded that the students of the teachers in this study are not getting the best of the teachers because the classes in most schools in the urban are obviously overcrowded. A total of $81(13.78 \%)$ of the responses to item 10 disagree with the notion that individual students can enjoy adequate attention from the teacher in a large ESL class. This is contrary to the advice that teachers in large classes should make every effort required to give so much individual attention to individual students as to know and address each by his or her name, and encourage each student to participate actively in class discussion and exercises.

Research Question 2: Do the English Language teachers adopt interactive and cooperative strategies in teaching reading comprehension in their large classes?

Table 6: Teachers' Self-Reports of their Pedagogic Practices in Reading Comprehension in Large ESL Classes

\begin{tabular}{|l|l|l|l|l|}
\hline S/N & Item & Yes & No & Total \\
\hline 11 & $\begin{array}{l}\text { Do the circumstances of your large class permit you to } \\
\text { engage your students in group/cooperative assignments in } \\
\text { reading comprehension exercises? }\end{array}$ & - & 98 & $\mathbf{9 8}$ \\
\hline 12 & $\begin{array}{l}\text { Do the characteristics of the students in your large classes } \\
\text { encourage you to arrange them for peer tutoring? }\end{array}$ & - & 98 & $\mathbf{9 8}$ \\
\hline 13 & $\begin{array}{l}\text { Are you able to give and mark as many reading } \\
\text { comprehension exercises as you would have deemed }\end{array}$ & 3 & 95 & $\mathbf{9 8}$ \\
\hline
\end{tabular}

Journal of Contemporary Issues in Education, 2017, 12(2), pp. 2-17. 


\begin{tabular}{|l|l|l|l|l|}
\hline & satisfactory if you were in a small class? & & & \\
\hline 14 & $\begin{array}{l}\text { Do the circumstances of your school permit you to specially } \\
\text { select literary passages outside of those in the recommended } \\
\text { English Language textbooks for reading comprehension } \\
\text { exercises }\end{array}$ & 2 & 96 & $\mathbf{9 8}$ \\
\hline Total & $\mathbf{5}$ & $\mathbf{3 8 7}$ & $\mathbf{3 9 2}$ \\
\hline
\end{tabular}

Table 6 shows that a total of 392 responses were received as indication of some of the teachers' pedagogic practices in teaching reading comprehension to their large ESL classes. However, 387 of them indicate that the strategies that literature reveals to have turned the potential ordeals of language teaching in large ESL classes into productive ventures (peer tutoring, cooperative learning, literary text based reading comprehension) are not in use in the respondents' large classes.

\section{Conclusion}

The findings from the current study show that most teachers of English Language in the Ibadan metropolis view a large class as beginning from thirty-one students. A majority of them see teaching reading comprehension to a large ESL class as an ordeal rather than an advantage or opportunity to impact positively on a large number of learners at the same time. Their negative attitude to teaching of reading comprehension to a large class would not permit them to consider employing best practices that turn the "curse" of teaching a large class into a "bundle of blessings".

The following recommendations are deemed necessary to ensure that the lackluster performance in reading comprehension and related aspects of English Language studies among Nigerian secondary school students is improved:

1. Government should revert to the lofty policy and practice of maintaining a maximum of thirty students per class for maximal learning outputs.

2. The various concerned teacher training institutions should emphasise inculcation of skills and attitudes required for effective and efficient teaching of reading comprehension and other learning contents so that pre-service English Language teachers may not be rendered ineffective in the eventuality of being confronted with the challenges posed by large ESL classes.

3. In-service re-training of serving English Language teachers in attitudes and skills required for successful teaching of language skills to large classes should be offered consistently. 4. School libraries should be stocked by the government with adequate literary books and students should be encouraged to read such books extensively so that their use for the teaching and learning of reading comprehension skills may be familiar to them.

Journal of Contemporary Issues in Education, 2017, 12(2), pp. 2-17. 


\section{References}

Abioye, T. (2010). Managing language testing in Nigerian large classes: Processes and prospects. English Language Teaching, 3(2), 82-87. http://dx.doi.org/10.5539/elt.v3n2p82

Adebayo, F. A. (2009). Parents' preference for private secondary schools in Nigeria. International Journal of Educational Sciences, 1(1), 1-6.

Akanbi, G. O. (2014). Future directions for education in Nigeria. 4th Distinguished Staff Lecture, Emmanuel Alayande College of Education, Oyo. Oyo: Research and Publications Committee, Emmanuel Alayande College of Education.

Aladejana, F. (2007). The implications of computer and NKS for science teaching: WhitherNigeria. Complex Systems, 17, 113-124.

Amanchukwu, R. N. \& Ololube, N. P. (2015). Managing school plant for effective service delivery in public secondary schools in Rivers State of Nigeria. Human Resource Management Research, 5(4), 95-102. http://dx.doi.org/10.5923/j.hrmr.20150504.02

Arikan, A. (2008). Topics of reading passages in ELT course books: What do our students really read? The Reading Matrix, 8(2),70-85.

Bahanshal, A. D. (2013). The effect of large classes on English Teaching and Learning in Saudi Secondary Schools. English Language Teaching, 6(11), 49-59. http://dx.doi.org/10.5539/elt.v6n11p49

Barjesteh, D., Alipour, B., \& Vaseghi, R. (2013). Critical pedagogy: Improving Iranian EFL learner's reading comprehension ability through CP strategies. Indian Journal of Fundamental and Applied Life Sciences. An Online International Journal, 3(3), 335-341.

Bradley, C., \& Green, E. (2011). Teaching effectively in large classes. University of Regina: Centre for Teaching and Learning.

Brantmeier, C. (2006). Toward a multicomponent model of interest and L2 reading: Sources of interest, perceived situational interest, and comprehension. Reading in a Foreign Language, 18(2). Available at https://pages.wustl.edu/files/pages/imce/brantmeierlanguageresearch/toward_a_multicom ponent_model.pdf

Chowdhury, K. B. (2012). Communicative language teaching approach at higher secondary level in Bangladesh - Teachers' perceptions and classroom practice. Language in India. Strength for Today and Bright Hope for Tomorrow, 12(2), 1-78.

Christopher, N. M. (2006). Books, education and literacy in Nigeria's development. Literacy and Reading in Nigeria, 11(1), 56-69.

Danladi, S. S. (2013). Language policy: Nigeria and the role of English language in the $21^{\text {st }}$ century. European Scientific Journal, ESJ, 9(17).

Emeka-Nwobia, N. U. (2015). The place of indigenous Nigerian languages in national development. Research on Humanities and Social Sciences, 5(12), 112-116.

Emenanjo, N. M. (2014). How safe is the book today? Monograph Series No. 4. Ibadan: University Press Plc.

Gilakjan, A. P., \& Ahmadi, S. M. (2011). The relationship between L2 reading comprehension and schema theory: A matter of text familiarity. International Journal of Information and Education Technology, 1(2), 142-149. 
Hansen, J. H., \& Hasan, T. (2015). Speaker recognition by machines and humans: A tutorial review. IEEE Signal processing magazine, 32(6), 74-99. http://dx.doi.org/10.1109/MSP.2015.2462851

Hayes, D. (1997). Helping teachers to cope with large classes. ELT Journal, 51(2), 106-116. Hess, N. (2001). Teaching large multilevel classes. Cambridge: CUP.

Imitaz, S. (2014). Exploring strategies for English Language Teaching of Pakistani students in public sector colleges. Research Journal of English Language and Literature (RJELAL), 2(2), 247-253.

Jimakorn, P., \& Singhasiri, W. (2006). Teachers' beliefs concerning large-class English teaching at the university level. Reflections KMUTT Journal of Language Education, 9, 13-23.

Inyang, S., \& Onukaogu, C.E. (2003). Operating reading clubs in our schools and colleges. In C.E. Onukaogu, A.E. Arua, \& O.B. Jegede (Eds.). Teaching reading in Nigeria: A guidebook to theory and practice ( $2^{\text {nd }}$ ed.) (pp. 195-210). Newark: International Reading Association.

Iroegbu, V. I. (1997). Effects of modelling and computer-based instructional strategies on primary school pupils' learning outcomes in English Language. Ph.D. Thesis. Department of Teacher Education, University of Ibadan, Nigeria.

Kainuwa, A., \& Yusuf, N. B. M. (2013). Influence of socio-economic and educational background of parents on their children's education in Nigeria. International Journal of Scientific and Research Publications, 3(10), 1-8.

Kolawole, C.O.O. (2005). The state of reading in selected secondary schools in South-Western Nigeria: A preliminary report. In A. Dada, A. Abimbade, \& O. O. Kolawole (Eds.) Issues in language, communication and education. A book in honour of Caroline A. Okedara (pp. 98-109). Ibadan and Abuja: Counstellations Books.

Maduewesi, B. U., \& Ihebereme, C. I. (2010). Professionalization of teaching: A prospect for effective skill acquisition at the primary education level. Academic Scholarship Journal, $2,1-7$.

Maingi, D., Mulwa, D., Maithya, R., \& Migosi, J. (2017). Influence of school physical facilities on students' discipline in public secondary schools in Makueni County, Kenya. American Journal of Education and Learning, 2(1), 34-42. http://dx.doi.org/10.20448/804.2.1.34.42

McNabb, G. (2013). Using online technologies to improve reading ability in EFL learners. Journal of Literature in Language Teaching, 2, 39-44.

Mirvan, X. (2013). The advantages of using films to enhance students' reading skills in the EFL classroom. Journal of Education and Practice, 4(13), 62-66.

National Educational Research and Development Council (NERDC) (1998). National Policy on Education 3rd Ed. Lagos: NERDC Press.

National Educational Research and Development Council (NERDC) (2004). National Policy on Education 4th Ed. Lagos: NERDC Press.

National Educational Research and Development Council (NERDC) (2013). National Policy on Education 6th Ed. Lagos: NERDC Press.

Nevara, J., \& Greisamer, M. (2010). Teaching to the masses: Managing the large sized EFL class. Available at http://www.kobegakuin.ac.jp/facility/fdc/journal/edc_journal/pdf/j-301.pdf

Nwokeoma, J. (2010). Exam Failure, Education Minister and the Dearth of Teachers in Nigeria. The Will. Available at

Journal of Contemporary Issues in Education, 2017, 12(2), pp. 2-17. 
http://thewillnigeria.com/opinion/5994-EXAM-FAILURE-EDUCATION-MINISTER_AND-THE-DEARTH-TEACHERS-NIGERIA.html

Ogunbiyi, O. (2004). New challenges in the methodologies of teaching: A case for in-service programme for school teachers. In D.F. Elaturoti, \& K. Babarinde (Eds.). Teachers' mandate on education and social development in Nigeria (pp. 152-157). Ibadan: StirlingHorden Publishers.

Okebukola, P. A. (2012). Long live the author. Monograph Series No. 2. Ibadan: University Press Plc.

Okebukola, P. A., Owolabi, O., \& Okebukola, F. O. (2013). Mother tongue as default language of instruction in lower primary science classes: Tension between policy prescription and practice in Nigeria. Journal of Research in Science Teaching, 50(1), 62-81. http://dx.doi.org/10.1002/tea.21070

Okediran, A, \& Olatunji, S.O. (2010). New horizons in the use of Nigerian indigenous languages in education. Ghana Journal of Education and Teaching, 11, 183-198.

Olaotan, C. E., \& Ogunleye, M. M. B. (2013). Techniques for developing the reading culture of Nigeria children. COCLIN Journal of Library and Information Science, 6 (1\&2), 57-68.

Olatunji, S.O. (2000). French as second official language in Nigerian secondary schools; Problems and prospects. M.Ed. Dissertation. Ibadan: University of Ibadan.

Oleforo, N. A., \& Maxwell, M. E. (2015). Principals' school plant management and academic performance of biology students in public secondary schools in Uyo Senatorial District, Akwa Ibom State. International Journal of Education and Practice, 3(8), 241-249. http://dx.doi.org/10.18488/journal.61/2015.3.8

Onukaogu, C.E. (2003). Towards the understanding of reading. In C.E. Onukaogu, A.E. Arua, \& O.B. Jegede (Eds.). Teaching reading in Nigeria: A guidebook to theory and practice. ( $2^{\text {nd }}$ ed.). (pp. 1-35). Newark: International Reading Association.

Osisanwo, W. (2005). The English Language in Nigeria: A blessing or a cog in the wheel of progress. Special Lecture Series 01. Ondo: Adeyemi College of Education.

Osoba, J. B., \& Alebiosu, T. A. (2016). Language preference as a precursor to displacement and extinction in Nigeria: The roles of English language and Nigerian Pidgin. Journal of Universal Language, 17(2), 111-143. http://dx.doi.org/10.22425/jul.2016.17.2.111

Ozkan, A., \& Tongur, N. A. (2014). Use of literature in reading comprehension classes by ELT teachers. The International Journal of Social Sciences, 25, 66-72.

Pedder, D. (2006). Are small classes better? Understanding relationships between class size, classroom processes and pupils' learning. Oxford Review of Education, 32(2), 213-234. http://dx.doi.org/10.1080/03054980600645396

Reinders, H., \& Balcikanli, C. (2011). Do classroom textbooks encourage learner autonomy? Novitas-Royal (Research on Youth and Language), 5(2), 265-272.

Roberts, M. (2007). Teaching in the multilevel classroom. Pearson Education, Inc. Available at http://www.pearsonlongman.com/ae/download/adulted/multilevel_monograph.pdf

Roessingh, H., \& Field, D. (2000). Time, timing, timetabling: Critical elements of successful graduation of high school ESL learners. TESL Canada Journal/Revue TESL du Canada, 18(1), 17-31.

Shamim, F. (1993). Teacher-learner behaviour and classroom processes in large ESL classes in Pakistan. Ph.D. Thesis. University of Leeds. 
Sharndama, E. C. (2013). Application of ICTs in teaching and learning English (ELT) in large classes. Journal of Arts and Humanities (JAH), 2(6), 34-39.

Suh, J. S. (2009). Reading concepts in cooperative work by EFL college students. English Teaching, 64(2), 151-171. http://dx.doi.org/10.15858/engtea.64.2.200906.151

Thaher, M. (2005). The effects of large class on EFL students at An-Najah National University. An-Najah Univ. Journal of Research (Humanities), 19(3), 1047-1092.

Todd, R. W. (2006). Why investigate large classes? Reflections KMUTT Journal of Language Education, 9, 1-12.

Treko, N. (2013). The big challenge: Teaching large multi-level classes. Academic Journal of Interdisciplinary Studies, 2(4), 243-251. http://dx.doi.org/10.5901/ajis.2012.v2n4p243

Ozkan, A. \& Tongur, A. N. (2012). Use of Literature in Reading Comprehension Classes by ELT Teachers. The International Journal of Social Sciences 25(1), 66-72.

Ur, P. (1996). A course in language teaching: Practice and theory. Cambridge: Cambridge University Press.

Van Lier, L. (2014). Interaction in the language curriculum: Awareness, autonomy and authenticity. London \& New York: Routledge.

Wang, Q., \& Zhang, N. (2011). Teaching large classes in China - English as a foreign language. Applied Linguistics. University of Warwick. Available at https://www2.warwick.ac.uk/fac/soc/al/research/groups/llta/resources/telc/5._wang_qiang _overview_of_china_research_0.pdf

Willis, $\bar{D}$., \& Willis, J. (2007). Doing task-based teaching. Oxford: Oxford University Press.

Worthy, J., Moorman, M., \& Turner, M. (1999). What Johnny likes to read is hard to find in school. Reading Research Quarterly, 34(1), 12-27. http://dx.doi.org/10.1598/RRQ.34.1.2

Xhemaili, M. (2013). The advantages of using films to enhance student's reading skills in the EFL classroom. Journal of Education and Practice, 4(13), 62-66.

Yadav, S. (2014). Recognizing the importance of literature and integration in ELT classes. International Journal of Education and Research, 2(9), 393-400.

Yugandhar, K. (2013). Elevating language learning ambiance using literature-based activities in E-Class. International Journal of English and Education, 2(2), 388-393.

Zhang, X., \& Hung, S. C. (2013). A case study of exploring viability of task-based instruction on college English teaching in big-sized class. Journal of Language Teaching \& Research, 4(4), 693-699. http://dx.doi.org/10.4304/j1tr.4.4.693-699 